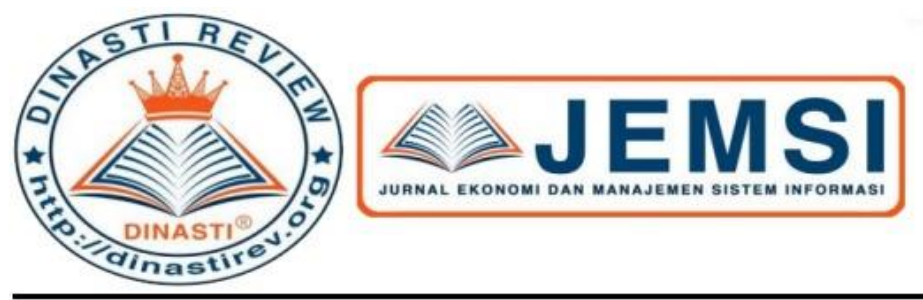

+62 878-9658-6407

087896586407 ()

https://dinastirev.org/JEMSI (-)

editor@dinastirev.org (G.

\title{
PENGEMBANGAN UNIVERSITAS PUTRA INDONESIA "YPTK" PADANG BERDASARKAN ANALISIS SWOT
}

Hilda Mary ${ }^{1)}$

1) Universitas Putra Indonesia "YPTK", Padang, Indonesia

ARTICLE INFORMATION

Received: 2 April 2020

Revised: 12 April 2020

Issued: 24 April 2020

Corresponding author:

Hilda Mary

E-mail:

hildamary@upiyptk.ac.id

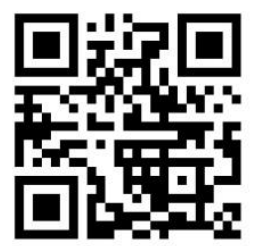

DOI:10.31933/JEMSI
Abstrak: Dalam menghadapi persaingan yang ketat saat ini Perguruan Tinggi Swasta harus memiliki strategi dalam menghadapinya. Untuk itulah Perguruan Tinggi Swasta berupaya dalam meningkatkan mutu layanan yang mesti dikelola dengan baik dan transparan. Universitas Putra Indonesia YPTK Padang salahsatunya, yang harus mempersiapkan diri dalam menghadapi tantangan globalisasi dan teknologi melalui serangkaian kebijakan yang strategis dan taktis. Kebijakan yang dimaksud adalah mewujudkan sistem yang terprogram dan terstruktur. Tujuan dari penelitian ini adalah mendeskripsikan Universitas Putra Indonesia YPTK Padang melaui Analisa SWOT yang dapat bermanfaat untuk menetapkan pilihan yang strategis untuk kedepannya. Hasil dari penelitian ini menunjukan pilihan yang strategis dan taktis dengan potensi yang dimiliki untuk tetap survive dimasa yang akan datang.

Kata Kunci: Pengembangan, UPI-YPTK Padang dan Analisa SWOT.

\section{PENDAHULUAN}

Perguruan tinggi swasta di Indonesia harus mempunyai strategi untuk menghadapi tantangan yang akan dihadapi kedepannya. Untuk itu perguruan tinggi tersebut harus memiliki strategi untuk menghadapai tantangan dan ancaman yang terjadi saat ini maupun untuk dimasa yang akan datang dengan mempertimbangkan kekuatan dan kelemahan yang dimilikinya.

Strategi dalam menghadapi tantangan dan ancaman yang terjadi saat ini maupun yang akan datang harus mempertimbangkan kekuatan dan kelemahan yang dimilikinya. Upaya mengoptimalkan mutu layanan PTS yang dikelola dengan baik dan transparan, dan dikembangkan berlandaskan visi dan misi yang jelas, dan diikuti dan dilaksanakan oleh setiap individu yang terlibat di dalamnya (Nyoman, 2017).

Manajemen strategis terdiri dari analisis, keputusan dan tindakan organisasi dalam rangka menciptakan dan mempertahankan keunggulan kompetitif. Proses manajemen 
strategis adalah sebuah analisis dan pilihan yang dapat meningkatkan kemungkinan bahwa organisasi akan memilih "strategi yang baik" yang menghasilkan keuntungan yang kompetitif (Emel Gurel, 2017)

Yayasan Perguruan Tinggi Komputer, Padang, yang berdiri pada tahun 1985 dan telah mengembangkan diri menjadi Universitas Putra Indonesia "YPTK" Padang pada tahun 2001, dari tahun ke tahun terus membuka program studi baru. Adapun tujuannya adalah meningkatkan kualitas SDM, lulusan, organisasi, manajemen dan pelaksanaan tridharma perguruan tinggi, sehingga UPI-YPTK Padang dapat secara maximal berperan sebagai pusat pembelajaran, penelitian, pengembangan ilmu pengetahuan, teknologi, seni dan komunikasi.

Maksud dan tujuan dari tulisan ini adalah membuat pemetaan SWOT analysis berdasarkan pendekatan analisis internal environment thralth to opportunity profil. Berdasarkan pemetaan tersebut dapat dirancang strategi dan solusi dalam menghadapi masalah internal dan eksternal.

\section{KAJIAN PUSTAKA}

Intellectual Capital adalah tiga pilar modal dalam perguruan tinggi yaitu (a) human capital yaitu pengetahuan dan kreativitas atau pengalaman dalam melakukan sesuatu yang menghasilkan nilai ekonomi, (b) structural capital yaitu infrastruktur non-fisik yang mendukung dan memungkinkan berfungsinya human capital untuk mencapai tujuan institusi, (c) relational capital merupakan hubungan perusahaan dengan pelanggan, vendor dan konstituensi lainnya, yang mencakup pengetahuan, kemampuan, prosedur dan sistem yang dikembangkan dengan pihak eksternal (Yusuf et al, 2014).

Kekuatan adalah sesuatu yang dilakuakan sebuah organisasi dengan baik atau karakteristik organisasi yang memberikan kemampuan yang sangat penting (Thompson dan Strickland, 1989: 109). Dalam konteks ini "kekuatan adalah sumber daya, keterampilan, atau lainnya keuntungan relatif terhadap pesaing dan kebutuhan pasar, organisasi berfungsi atau mengharapkan untuk melayani. Ini adalah kompetensi khas yang memberikan organisasi keunggulan komparatif di pasar. Kekuatan mungkin ada sehubungan dengan sumber daya keuangan, citra, kepemimpinan pasar, hubungan pembeli/pemasok, dan faktor-faktor lain"(Pearce dan Robinson, 1991: 182).

Kekuatan organisasi terdiri dari kompetensi organisasi memainkan peran aktif dalam mencapai tujuan organisasi. Sebelum pergi ke dalam kekuatan organisasi terdiri dari kompetensi organisasi memainkan peran aktif dalam mencapai tujuan organisasi. Sebelum pergi ke dalam tindakan ketika mengalami masalah atau peluang, sebuah organisasi harus mengetahui potensi bahwa ia memiliki dan aspek yang membuatnya lebih menguntungkan dibandingkan pesaingnya. Menjadi kuat dan memiliki kekuatan yang cukup penting bagi suatu organisasi. Jika tidak, peluang yang diciptakan oleh lingkungan luar tidak dapat digunakan. Selain itu, organisasi harus menjawab dengan ancaman dari lingkungan luar dengan menggunakan kekuatan. Semua masalah ini menyoroti pentingnya kekuatan organisasi (Ülgen dan Mirze, 2010: 161).

Analisis SWOT adalah suatu kerangka kerja perencanaan strategis yang digunakan dalam evaluasi suatu organisasi, rencana, proyek atau kegiatan bisnis. Oleh karena itu Analisis SWOT adalah alat yang penting untuk analisis situasi yang membantu para manajer untuk mengidentifikasi faktor-faktor organisasi dan lingkungan. Analisis SWOT memiliki dua dimensi: internal dan eksternal. dimensi internal meliputi faktor organisasi, juga kekuatan 
dan kelemahan, dimensi eksternal meliputi faktor lingkungan, juga peluang dan ancaman (Emel Gurel, 2017)

\section{METODE PENELITIAN}

Analisis dengan menggunakan pendekatan SWOT (strength, weakness, opportunity and threat), tinjauan yang berdasarkan pada kekuatan dan kelemahan internal institusi. Peluang dan ancaman yang akan dihadapi dari eksternal, serta strategi pengembangan yang akan dilakukan untuk menghadapi beberapa puluh tahun kedepannya.

\section{HASIL DAN PEMBAHASAN}

Analisis SWOT UPI-YPTK Padang secara keseluruhan yang ditinjau dari aspek masukan, proses dan keluaran, yang dibagi dalam dua hal yaitu analisis antar komponen, strategi dan pengembangan, dengan uraian sebagai berikut:

A. Aspek Masukan

Aspek masukan meliputi: visi, misi, sasaran dan tujuan, mahasiswa, dosen dan tenaga pendukung, kurikulum, sarana dan prasarana, biaya dan sumber dana.

1) Strength $(\mathrm{S})$

UPI-YPTK Padang mempunyai visi, misi, sasaran dan tujuan, mahasiswa, dosen dan tenaga pendukung, kurikulum, sarana dan prasarana, biaya dan sumber dana, senantiasa focus dalam mengembangkan ilmu pengetahuan dan teknologi serta aplikasinya. Dalam hal inilah daya tarik bagi calon mahasiswa untuk menempuh pendidikan di salah satu program studi yang ada di UPI-YPTK Padang. Dengan penyediaan fasilitas yang relatif lengkap, sarana dan prasarana yang mendukung kegiatan perkuliahan, dosen dan tenaga pendukungnya, serta kurikulum yang selalu diperbaharui, maka menjadi daya tarik tersendiri bagi calon mahasiswa. Untuk operasional dan pengembangan setiap program studi, dukungan dana dari UPIYPTK Padang cukup besar dan dikelola dengan sistem alokasi yang jelas dan transparan. Dosen dengan kualifikasi yang memadai dan tenaga pendukung di UPIYPTK Padang selalu dikembangkan melalui pembinaan serta adanya jaminan kesejahteraan yang mencukupi untuk menjamin kenyamanan kerja.

2) Weakness (W)

Sebagian besar tenaga pendidik telah berusia diatas 45 tahun yang membutuhkan kaderisasi yang terprogram dan terencana secara baik. Selain itu, dalam waktu 3 tahun terakhir jumlah peminat yang masuk ke sejumlah program studi cenderung belum meningkat. 
3) Opportunity $(\mathrm{O})$

Pertumbuhan ekonomi dan Industri yang berbasis sains dan teknologi saat ini berkembang demikian pesat dan membutuhkan sumber daya manusia yang: menguasai bidang sains dan teknologi. Peluang ini yang harus dapat ditangkap oleh UPI-YPTK Padang. Kerjasama dengan industri dapat ditingkatkan berupa pemberian beasiswa bagi karyawannya untuk melanjutkan studi di UPI-YPTK Padang, magang industri untuk dosen, penggalian dana proyek untuk pembiayaan program, penyediaan perangkat dan fasilitas serta sharing pengetahuan untuk menjembatani gap antara teori dan praktek di lapangan.

4) Treat $(\mathrm{T})$

Adanya program studi sejenis dengan program studi yang dikelola UPI-YPTK Padang, baik Perguruan Tinggi Swasta, Perguruan Tinggi Negeri maupun Perguruan Tinggi Asing, sehingga persaingan dalam merekrut calon mahasiswa baru, kompetisinya menjadi sangat ketat.

\section{Staregi Pengembangan}

Untuk mengatasi kelemahan dan ancaman serta menangkap peluang, dilakukan sejumlah pengembangan, antara lain: rekruitmen tenaga pendidik muda sebagai upaya kaderisasi, dan pengiriman study lanjut. Selain itu juga dilakukan kerjasama dengan instansi di dalam dan di luar negeri untuk pendidikan lanjut dosen, magang, dan kerjasama penelitian. Untuk meningkatkan motivasi dalam publikasi karya ilmiah nasional maupun internasional diberlakukan pemberian insentif penulisan karya ilmiah, serta dukungan bagi tenaga pendidik membuat karya unggulan yang dapat menjadi warna program studi.

\section{B. Aspek Proses}

Aspek proses meliputi: tata pamong, pengelolaan program, proses pembelajaran, suasana akademik, penelitian, tesis dan disertasi, serta penjaminan mutu. Pengkajian aspek proses dilakukan dengan melihat kegiatan operasional selama proses berlangsung.

1) Strength $(\mathrm{S})$

Secara keseluruhan proses penyelenggaraan pendidikan pada semua program studi di UPI-YPTK Padang telah berjalan cukup baik dan teratur, baik secara administratif maupun sistem akademik. Proses akademik dalam pelaksanaan proses pembelajaran telah berjalan dengan baik. Obyektifitas dan mutu dalam proses akademik diupayakan dijaga dengan adanya rapat koordinasi dan rapat pimpinan yang merupakan sarana pengambilan keputusan tertinggi dalam memecahkan masalah-masalah pada setiap program studi. Komitmen tenaga pendidik dan keseriusan mahasiswa ditunjukkan dengan prosentase kehadiran perkuliahan yang tinggi, kegiatan akademik di luar kelas yang dilakukan mahasiswa juga cukup tinggi. Adanya Buku Panduan Akademik dan aturan akademik pendukungnya memberikan kejelasan aturan dan norma yang ada dalam setiap kegiatan belajar. 
Proses pembelajaran juga didukung oleh suasana akademik yang kondusif yang meliputi suasana lingkungan, keamanan, kegiatan-kegiatan ilmiah (seminar, presentasi, diskusi, dlsb), ruang aktivitas akademik mahasiswa (laboratorium, studio), serta unit-unit kegiatan kemahasiswaan. Kerjasama dan kemitraan dengan institusi lain diharapkan meningkatkan motivasi maupun kompetensi tenaga pendidik dalam proses akademik. Dengan suasana akademik yang mendukung proses pembelajaran ini, proses pembelajaran dapat mencapai hasil yang lebih optimal, karena proses pembelajaran tidak hanya dilakukan di ruang kelas.

2) Weakness (W)

Kelemahan pada masing-masing program studi adalah sistem pendokumentasian, pengarsipan dan basis data yang masih belum optimal. Selain itu tumpang tindih pekerjaan operasional dan pengembangan serta banyaknya ragam pekerjaan yang harus dilakukan oleh staf mengakibatkan banyak hal paralel yang harus dikerjakan pada suatu saat. Hal ini mengurangi fokus pengerjaan dan seringkali menghasilkan keluaran yang tidak optimal. Ketidak sesuaian prosedur tentu saja akan menghambat pengambilan keputusan dan tindakan serta menimbulkan kebingungan dan ketidak konsistenan. Dalam proses pembelajaran kelemahannya adalah belum termanfaatkannya penggunaan peralatan Teknologi Informasi Komunikasi (TIK) secara maksimal.

3) Opportunity $(\mathrm{O})$

Peluang yang ada dalam proses pembelajaran adalah semakin terbukanya informasi melalui sarana Teknologi Informasi dan Komunikasi, sehingga kekurangan informasi, buku, pustaka, materi yang tidak tersedia pada setiap program studi dapat dicari melalui internet. Dengan sumber informasi yang sangat besar dari Teknologi Informasi dan Komunikasi juga akan meningkatkan kreativitas dan wawasan tenaga pendidik maupun mahasiswa, sehingga meningkatkan mutu proses pembelajaran. Melalui internet juga pengelolaan proses pembelajaran dapat dicari referensinya sebagai pembanding dari perguruan tinggi lain maupun dari standarstandar internasional yang berlaku.

4) Treat (T)

Hal yang menjadi ancaman dalam proses akademis ini adalah semakin terbukanya informasi dan adanya fasilitas Teknologi Informasi dan Komunikasi yang memadai sangat mungkin digunakan untuk hal-hal yang tidak semestinya, misalnya mudahnya melakukan plagiarisme, penggunaan internet untuk game online dsb.

\section{Staregi Pengembangan}

Untuk mengatasi kelemahan dan ancaman serta menangkap peluang, dilakukan beberapa pengembangan berupa peningkatan pemanfaatan teknologi informasi untuk pembelajaran (e-learning, ujian online, dan sejenisnya), peningkatan infrastruktur TIK (kapasitas bandwidth dan terminal), perbaikan sistem dokumentasi maupun digital. Selain itu juga akan dilakukan penyempurnaan Standar Operasional Prosedur (SOP) dan konsep penjaminan mutu pada masing-masing program studi. Disamping itu juga dipersiapkan untuk pemenuhan standard ISO. 
C. Aspek Keluaran

Aspek keluaran meliputi: Lulusan, publikasi ilmiah dan pengabdian kepada masyarakat.

1) Strength $(\mathrm{S})$

Sistem informasi pelacakan alumni telah tersedia dengan baik, melalui www.upiyptk.ac.id, milist alumni, reuni antar program studi dan executive gathering. Rencana pengembangan penelitian juga dilaksanakan secara terprogram dalam bentuk Rencana Induk Penelitian, sekaligus upaya perluasan skema pendanaannya.

2) Weakness (W)

Kelemahan utama dari penelitian adalah masih kurangnya motivasi meneliti dari para tenaga pendidik sebagai akibat beban pekerjaan dalam pengajaran, administratif serta organisasi masih cukup tinggi, sehingga alokasi waktu untuk penelitian kurang memadai. Hal ini berdampak terhadap jumlah penelitian dan publikasi ilmiah, baik nasional maupun international masih kurang. Akibat kelemahan ini, maka kerjasama penelitian dan pengabdian kepada masyarakat dengan pihak luar pun seringkali sulit dilaksanakan dan tidak berkesinambungan karena kurangnya fokus kompetensi.

3) Opportunity $(\mathrm{O})$

Perkembangan industri berbasis sains dan teknologi cenderung meningkat, sehingga akan dibutuhkan banyak sarjana, dan pada saat ini tingkat kepercayaan masyarakat industri kepada UPI-YPTK Padang masih tinggi. Ini merupakan peluang bagi lulusan yang ada dan peluang bagi pengembangan serta kerjasama penelitian dan pengabdian kepada masyarakat.

4) Treat (T)

Terbukanya dunia pendidikan di Indonesia untuk perguruan tinggi asing maupun tenaga kerja asing. Hal ini memperbesar tingkat persaingan di pasar tenaga kerja Indonesia. Untuk itu diperlukan peningkatan kompetensi dan kemampuan lebih dari lulusan.

Penelitian yang dilakukan pun seringkali sulit mengikuti perkembangan sains dan teknologi yang berjalan pesat dan mempunyai standar tinggi. Kondisi ini mengakibatkan penelitian yang dilakukan tidak dapat memenuhi kriteria mutu industri yang tinggi. Diperlukan strategi pemilihan topik dan prioritas penelitian yang dilakukan.

\section{Staregi Pengembangan}

Untuk mengatasi kelemahan dan ancaman serta menangkap peluang, dilakukan beberapa pengembangan berupa peningkatan pembekalan mahasiswa/lulusan dengan softskill, bahasa inggris, dan keterampilan sesuai kompetensi. Dalam bidang penelitian, peningkatan fasilitas/insentif bagi dosen dalam penelitian, publikasi, dan paten, serta meningkatkan kerjasama dengan institusi/industri dalam bidang penelitian. 


\section{Tabel}

Berdasarkan hasil analisis SWOT tersebut, maka rincian strategi pengembangan Institusi secara umum sebagai berikut:

Tabel 1. Matriks TOWS

\begin{tabular}{|c|c|c|}
\hline & KEKUATAN (STRENGTHS) & PROGRAM \\
\hline \multirow{10}{*}{ 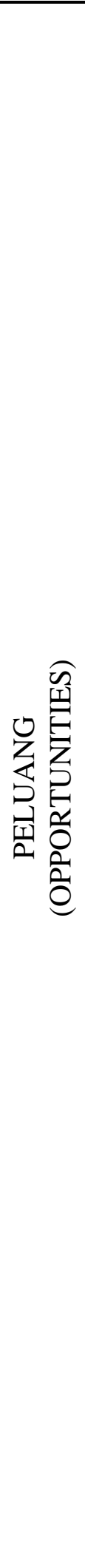 } & $\begin{array}{l}\text { 1. Menjalin kerjasama dengan } \\
\text { instansi baik pemerintah maupun } \\
\text { swasta dengan menawarkan } \\
\text { konsep yang bermanfaat bagi } \\
\text { masyarakat. }\end{array}$ & $\begin{array}{l}\text { 1. Menyelenggarakan pameran, } \\
\text { seminar ilmiah, pelatihan tenaga } \\
\text { edukatif dan non edukatif, } \\
\text { pengiriman dosen mengikuti } \\
\text { seminar nasional/internasional. }\end{array}$ \\
\hline & $\begin{array}{l}\text { 2. Memperluas jaringan ke } \\
\text { SMA/SMK/MA. }\end{array}$ & $\begin{array}{l}\text { 2. Pengiriman brosur ke } \\
\text { SMA/SMK/MA ke daerah-daerah, } \\
\text { pemasangan iklan pada koran } \\
\text { daerah, mengundang siswa } \\
\text { SMA/SMK/MA dalam beberapa } \\
\text { kegiatan Mahasiswa; }\end{array}$ \\
\hline & $\begin{array}{l}\text { 3. Meningkatkan perolehan dana } \\
\text { penelitian dosen dari instansi lain, } \\
\text { dan meningkatkan publikasi } \\
\text { penelitian dosen. }\end{array}$ & $\begin{array}{l}\text { 3. Lokakarya pembuatan proposal } \\
\text { penelitian yang bekerjasama } \\
\text { dengan LPPM UPI-YPTK Padang. } \\
\text { Membuat jurnal ilmiah yang } \\
\text { berkaitan dibidang keilmuan } \\
\text { masing-masing. }\end{array}$ \\
\hline & $\begin{array}{l}\text { 4. Menerapkan kurikulum berbasis } \\
\text { kompetensi. }\end{array}$ & $\begin{array}{l}\text { 4. Rapat evaluasi kurikulum, } \\
\text { penyusunan profil lulusan, bahan } \\
\text { kajian, matakuliah dan metode } \\
\text { pembelajaran. }\end{array}$ \\
\hline & $\begin{array}{l}\text { 5. Menjalin kerjasama dengan } \\
\text { berbagai pihak dalam } \\
\text { pengembangan sarana prasarana. }\end{array}$ & $\begin{array}{l}\text { 5. Menyusun proposal program } \\
\text { Hibah kompetisi. }\end{array}$ \\
\hline & $\begin{array}{l}\text { 6. Menjalin kerja sama dalam hal } \\
\text { pendanaan }\end{array}$ & $\begin{array}{l}\text { 6. Pembuatan proposal untuk bantuan } \\
\text { dana dari lembaga pemerintah dan } \\
\text { swasta. }\end{array}$ \\
\hline & $\begin{array}{l}\text { 7. Menjalin kerjasama dengan pihak } \\
\text { luar dalam pengembangan semua } \\
\text { program studi. }\end{array}$ & $\begin{array}{l}\text { 7. Mengadakan seminar dan diskusi } \\
\text { dengan Pihak pemangku } \\
\text { kepentingan dan pemerintah untuk } \\
\text { mengembangkan semua program } \\
\text { studi }\end{array}$ \\
\hline & $\begin{array}{l}\text { 8. Mengembangkan tata pamong } \\
\text { sesuai dengan pengembangan } \\
\text { semua program studi oleh UPI- } \\
\text { YPTK Padang. }\end{array}$ & $\begin{array}{l}\text { 8. Menambah SDM yang membantu } \\
\text { program studi. }\end{array}$ \\
\hline & $\begin{array}{l}\text { 9. Meningkatkan penggunaan } \\
\text { teknologi informasi dalam proses } \\
\text { belajar mengajar. }\end{array}$ & $\begin{array}{l}\text { 9. Penggunaan TIK dalam mengajar, } \\
\text { meningkatkan pemberian tugas } \\
\text { mahasiswa melalui internet. }\end{array}$ \\
\hline & $\begin{array}{l}\text { 10. Meningkatkan kerjasama dan } \\
\text { kemitraan dalam penelitian, } \\
\text { seminar dan pengabdian } \\
\text { masyarakat. }\end{array}$ & $\begin{array}{l}\text { 10. Menjalin kerjasama penelitian dan } \\
\text { pengabdian kepada masyarakat } \\
\text { dengan lembaga pemerintah dan } \\
\text { swasta }\end{array}$ \\
\hline
\end{tabular}




\begin{tabular}{|c|c|c|}
\hline & $\begin{array}{l}\text { 11. Meningkatkan akses dengan } \\
\text { pihak luar dalam perolehan } \\
\text { informasi. }\end{array}$ & $\begin{array}{l}\text { 11. Mendatangkan pihak pemangku } \\
\text { kepentingan, pemerintahan, dalam } \\
\text { hal pengrekruitmen lulusan. }\end{array}$ \\
\hline & $\begin{array}{l}\text { 12. Meningkatkan kerjasama dengan } \\
\text { stakeholder untuk mutu lulusan. }\end{array}$ & $\begin{array}{l}\text { 12. Membuat perjanjian kerjasama } \\
\text { penelitian dengan lembaga terkait } \\
\text { baik dalam maupun luar negeri }\end{array}$ \\
\hline & $\begin{array}{l}\text { 13. Meningkatkan rekuitmen tenaga } \\
\text { kerja oleh stakeholder. }\end{array}$ & $\begin{array}{l}\text { 13. Mengoptimalkan pelaksanaan } \\
\text { Sistem Penjaminan Mutu dan } \\
\text { mempersiapkan penerapan standar } \\
\text { ISO }\end{array}$ \\
\hline \multirow{9}{*}{ 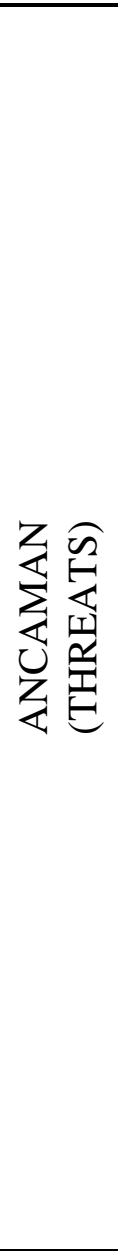 } & $\begin{array}{l}\text { 1. Melengkapi fasilitas dan } \\
\text { meningkatkan akreditasi. }\end{array}$ & $\begin{array}{l}\text { 1. Penambahan perlengkapan } \\
\text { studio/laboratorium, seperti } \\
\text { software dan hardware, merapikan } \\
\text { sistem pengarsipan dokumen }\end{array}$ \\
\hline & $\begin{array}{l}\text { 2. Meningkatkan penerapan tata } \\
\text { tertib mahasiswa }\end{array}$ & $\begin{array}{l}\text { 2. } \begin{array}{l}\text { Mengsosialisasikan tata tertib } \\
\text { mahasiswa terutama disiplin }\end{array} \\
\end{array}$ \\
\hline & $\begin{array}{l}\text { 3. Meningkatkan kualitas dan } \\
\text { kompetensi }\end{array}$ & $\begin{array}{l}\text { 3. Mengirim dosen untuk studi lanjut } \\
\text { (S-3) serta mengusulkan dosen } \\
\text { untuk meningkatkan jenjang } \\
\text { kepangkatan akademik }\end{array}$ \\
\hline & $\begin{array}{l}\text { 4. Menjalin kerjasama dengan } \\
\text { stakeholder dan meminta } \\
\text { masukan tentang kebutuhan dunia } \\
\text { kerja. } \\
\end{array}$ & $\begin{array}{l}\text { 4. Mendatangkan stakeholder dalam } \\
\text { acara diskusi tentang kebutuhan } \\
\text { dunia kerja. }\end{array}$ \\
\hline & $\begin{array}{l}\text { 1. Efisiensi dan efektifitas } \\
\text { penggunaan dana. }\end{array}$ & $\begin{array}{l}\text { 5. Mengefisienkan penggunaan dana } \\
\text { dengan mengurangi dana tak } \\
\text { terduga. }\end{array}$ \\
\hline & 2. Melengkapi perangkat kurikulum. & 6. Mengevaluasi GBPP/RPS. \\
\hline & $\begin{array}{l}\text { 3. } \begin{array}{l}\text { Meningkatkan perolehan dana } \\
\text { dari instansi luar untuk penelitian } \\
\text { dan pengabdian masyarakat. }\end{array} \\
\end{array}$ & $\begin{array}{ll}\text { 7. } & \text { Pembuatan proposal untuk } \\
\text { mendapatkan dana penelitian dan } \\
\text { pengabdian masyarakat. }\end{array}$ \\
\hline & $\begin{array}{ll}\text { 4. } & \text { Mengoptimalkan pemakaian } \\
\text { jaringan informasi kampus. }\end{array}$ & 8. Memperluas pemasangan hotspot. \\
\hline & $\begin{array}{l}\text { 5. Meningkatkan sarana } \\
\text { laboratorium untuk penelitian. }\end{array}$ & $\begin{array}{l}\text { 9. Pengadaan Laboratorium } \\
\text { penelitian. }\end{array}$ \\
\hline & KELEMAHAN (WEAKNESSES) & PROGRAM \\
\hline \multirow{2}{*}{ 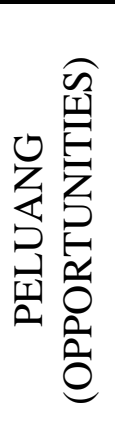 } & $\begin{array}{l}\text { 1. Sosialisasi visi dan misi diseluruh } \\
\text { kampus dan masyarakat luas. }\end{array}$ & $\begin{array}{l}\text { 1. Memasang leaflet visi dan misi } \\
\text { diruang kelas, laboratorium, } \\
\text { diruang pelayanan mahasiswa, } \\
\text { ruang dosen, memuat visi dan misi } \\
\text { pada brosur Program studi. }\end{array}$ \\
\hline & $\begin{array}{l}\text { 2. Meningkatkan pelayanan kepada } \\
\text { Mahasiswa agar kompetensi } \\
\text { lulusan sesuai kebutuhan } \\
\text { pemangku kepentingan }\end{array}$ & $\begin{array}{l}\text { Memaksimalkan pemakaian sistem } \\
\text { informasi untuk administrasi } \\
\text { mahasiswa dan melengkapi data } \\
\text { mahasiswa. }\end{array}$ \\
\hline
\end{tabular}




\begin{tabular}{|c|c|c|c|c|}
\hline & & $\begin{array}{l}\text { Meningkatkan sistem kaderisasi } \\
\text { tenaga edukatif dan } \\
\text { meningkatkan penulisan karya } \\
\text { ilmiah dosen. }\end{array}$ & 3. & $\begin{array}{l}\text { Menugaskan dosen muda } \\
\text { mendampingi dosen senior, dosen } \\
\text { menyerahkan } 2 \text { buah karya ilmiah } \\
\text { setiap semester untuk dipublikasi. }\end{array}$ \\
\hline & & $\begin{array}{l}\text { Menyempurnakan fasilitas dan } \\
\text { perangkat kurikulum. }\end{array}$ & 4. & $\begin{array}{l}\text { Penambahan sarana komputer, } \\
\text { LCD dan menyempurnakan RKPS } \\
\text { (Rencana Kegiatan Perkuliahan } \\
\text { Semester) }\end{array}$ \\
\hline & & $\begin{array}{l}\text { Mengoptimalkan dana yang ada } \\
\text { untuk pemeliharaan gedung /alat }\end{array}$ & 5. & $\begin{array}{l}\text { Memperbaiki ruang-ruang kaprodi, } \\
\text { dosen dan kuliah yang mengalami } \\
\text { kerusakan. }\end{array}$ \\
\hline & 6 . & $\begin{array}{l}\text { Penambahan tenaga edukatif dan } \\
\text { non edukatif. }\end{array}$ & 6. & $\begin{array}{l}\text { Menambahan jumlah tenaga } \\
\text { pendidik tetap. }\end{array}$ \\
\hline \multirow{9}{*}{ 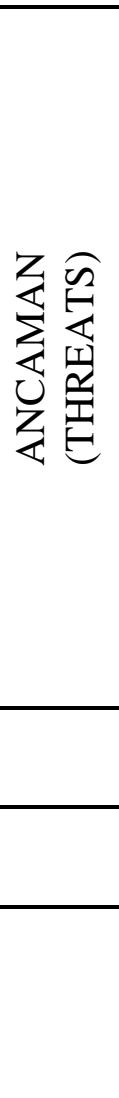 } & & $\begin{array}{l}\text { Menyamakan pola pikir } \\
\text { Mahasiswa baru. }\end{array}$ & 1. & Pengenalan lingkungan kampus. \\
\hline & & $\begin{array}{l}\text { Meningkatkan kuantitas dan } \\
\text { kualitas dosen. }\end{array}$ & 2. & Menambah jumlah dosen tetap. \\
\hline & & $\begin{array}{l}\text { Menambah jumlah matakuliah } \\
\text { pilihan yang relevan dengan } \\
\text { kompetensi lulusan. }\end{array}$ & & $\begin{array}{l}\text { Mengevaluasi matakuliah pilihan } \\
\text { yang sudah ada. }\end{array}$ \\
\hline & & $\begin{array}{l}\text { Meningkatkan pemeliharaan } \\
\text { terhadap sarana prasarana yang } \\
\text { sudah ada. }\end{array}$ & & $\begin{array}{l}\text { Perbaikan fasilitas perpustakaan } \\
\text { dan Laboratorium. }\end{array}$ \\
\hline & & $\begin{array}{l}\text { Memprioritaskan penggunaan } \\
\text { dana belajar mengajar }\end{array}$ & & $\begin{array}{l}\text { Prioritas penggunaan dana untuk } \\
\text { praktik }\end{array}$ \\
\hline & & $\begin{array}{l}\text { Meningkatkan belajar mandiri } \\
\text { Mahasiswa. }\end{array}$ & 6. & $\begin{array}{l}\text { Membuat panduan dan } \\
\text { menerapkan softskill dan hardskill. }\end{array}$ \\
\hline & & $\begin{array}{l}\text { Mengoptimalkan interaksi dosen } \\
\text { Mahasiswa. }\end{array}$ & 7. & $\begin{array}{l}\text { Mengadakan kuliah tamu dan } \\
\text { kuliah umum. }\end{array}$ \\
\hline & & $\begin{array}{l}\text { Mengoptimalkan pemakaian } \\
\text { internet kampus. }\end{array}$ & 8. & Menambah hotspot. \\
\hline & & $\begin{array}{l}\text { Mengoptimalkan penelitian dosen } \\
\text { dan mahasiswa. }\end{array}$ & & $\begin{array}{l}\text { Pembuatan proposal penelitian } \\
\text { untuk dilaksanakan dilaboratorium } \\
\text { sendiri atau bekerjasama dengan } \\
\text { instansi lain. }\end{array}$ \\
\hline
\end{tabular}

\section{KESIMPULAN DAN SARAN}

Paradigma perkembangan dan adanya regulasi banyak membawa dampak terhadap UPI-YPTK Padang. SDM merupakan hal yang krusial dalam meningkatkan daya saing, juga dalam hal meningkatkan daya saing lulusan yang dilandasi dengan kecerdasan spiritual, emosional and intelektual. Melalui analisis SWOT akan dapat bermanfaat untuk memahami potensi yang dimiliki UPI-YPTK Padang untuk kedepannya. 


\section{DAFTAR RUJUKAN}

Emel Gurel. 2017. SWOT ANALYSIS: A THEORETICAL REVIEW. Uluslararasi Sosyal Araştırmalar Dergisi The Journal of International Social Research, 10(51), 6-11. https://doi.org/http://dx.doi.org/10.17719/jisr.2017.1832 SWOT

Nyoman, N., Ketut, N., \& Mekarsari, A. 2017. Pengembangan Perguruan Tinggi Swasta melalui Analisis SWOT. Prosiding Seminar : Revitalisasi Tata Kelola Perguruan Tinggi Juni 2017, 14, 178-191.

Yusuf, M., Samad, A., Stie, P., Bireuen, K., Swot, P., Stie, D., \& Bireuen -Aceh, K. (2014). Analisis Potensi Stie Kebangsaan Bireuen Dengan Pendekatan Swot. Jurnal Kebangsaan, 3(5).

THOMPSON, A. A. \& STRICKLAND, A. J. 1989. Strategy Formulation and Implementation, (4th Edition), USA: Irwin, Inc.

PEARCE, J. A. \& ROBINSON, R. B. 1991. Strategic Management, (4th Edition), USA: Irwin, Inc.

ÜLGEN, H. \& MİRZE, S. K. 2010. İşletmelerde Stratejik Yönetim, (5. Bask1), İstanbul: Beta Basım Yayım.

Ali, H. (2018). Modul Manajemen Strategic. Jakarta: UMB. 